\title{
The impact of lymphadenectomy on survival outcomes of ovarian clear cell carcinoma: a systematic review and meta-analysis
}

\author{
Yan Liu ${ }^{1}$, Changzhen Huang ${ }^{1}$, Ran Chu ${ }^{1}$, Xingsheng Yang ${ }^{1}$, Beihua Kong ${ }^{1}$, and Kun Song ${ }^{1}$ \\ ${ }^{1}$ Shandong University Qilu Hospital
}

December 6, 2021

\begin{abstract}
Background: The treatment strategies for ovarian clear cell carcinoma (OCCC) are the same as those for epithelial ovarian cancer. Due to the rarity of OCCC, no prospective studies of its surgery have been reported. Therefore, the therapeutic significance of lymphadenectomy for OCCC needs to be further clarified. Objectives: To assess the effectiveness of lymphadenectomy in patients with ovarian clear cell carcinoma by a meta-analysis. Search Strategy: The Web of Science, Scopus, PubMed, and other sources (e.g. Google Scholar) were searched from each database's earliest inception to June 2021. Selection Criteria: Englishlanguage publications of observational studies that investigated the role of lymphadenectomy in patients with OCCC were included. Data Collection and Analysis: The pooled hazard ratio (HR) and 95\% confidence interval (CI) were calculated. Main Results: The analysis demonstrated that lymphadenectomy is associated with significantly improved disease-specific survival $(\mathrm{DSS})(\mathrm{HR}=0.76 ; 95 \% \mathrm{CI}=0.60-0.95 ; \mathrm{P}=0.02 ; \mathrm{I} 2=0.0 \%)$ and disease-free survival $(\mathrm{DFS})(\mathrm{HR}=0.58 ; 95 \% \mathrm{CI}=0.33-1.00 ; \mathrm{P}=0.05$; $\mathrm{I} 2=61 \%)$, but not for overall survival $(\mathrm{OS})(\mathrm{HR}=0.80 ; 95 \% \mathrm{CI}=0.60-1.06 ; \mathrm{P}=0.12 ; \mathrm{I} 2=19 \%)$ and progression-free survival (PFS) $(\mathrm{HR}=0.95 ; 95 \% \mathrm{CI}=0.64-1.42 ; \mathrm{P}=0.79 ; \mathrm{I} 2=0.0 \%)$. But it is worth noting that several single studies indicated a tendency of improved OS, PFS, DFS, DSS with lymphadenectomy. Conclusions: Lymphadenectomy could not significantly improve OS and PFS for OCCC, but is associated with improved DFS and DSS. Gynecologic oncologists should tailor treatment to patients to achieve optimal outcomes. And further studies are necessary to validate the impact of lymphadenectomy on OCCC. Keywords: ovarian clear cell carcinoma, lymphadenectomy, survival, systematic review, meta- analysis
\end{abstract}

\section{Hosted file}

The impact of lymphadenectomy on survival outcomes of ovarian clear cell carcinoma.doc available at https://authorea.com/users/449720/articles/548213-the-impact-oflymphadenectomy-on-survival-outcomes-of-ovarian-clear-cell-carcinoma-a-systematicreview-and-meta-analysis

\section{Hosted file}

FIGURE LEGENDS. doc available at https://authorea.com/users/449720/articles/548213-the-impactof-lymphadenectomy-on-survival-outcomes-of-ovarian-clear-cell-carcinoma-a-systematicreview-and-meta-analysis 